\title{
Biodiversity of shallow-water brachiopods from New Caledonia, SW Pacific, with description of a new species
}

\author{
MARIA ALEKSANDRA BITNER \\ Institute of Paleobiology, Polish Academy of Sciences, ul. Twarda 51/55, 00-818 Warszawa, Poland. \\ E-mail: bitner@twarda.pan.pl
}

\begin{abstract}
SUMMARY: Twelve species of recent brachiopods belonging to the genera Lingula, Discradisca, Novocrania, Xenobrochus, Eucalathis, Frenulina, Argyrotheca, Campages, Thecidellina and Lacazella were identified in samples collected during shallow-water cruises around New Caledonia, southwest Pacific. Six genera, Lingula, Xenobrochus, Eucalathis, Frenulina, Campages and Thecidellina, have been already reported from the New Caledonian region, while four genera, Discradisca, Novocrania, Argyrotheca and Lacazella are the first records from this region. Additionally, Discradisca stella is the first discinid brachiopod recognized in the New Caledonia area. One new species is described, the megathyridid Argyrotheca neocaledonensis $\mathrm{n}$. sp. The biogeographical affinities of the New Caledonia brachiopod faunas are briefly discussed.
\end{abstract}

Keywords: recent brachiopods, biogeography, shallow water, New Caledonia, southwest Pacific, taxonomy, new species.

\begin{abstract}
RESUMEN: Biodiversidad de BRaQuiópodos de aguas someras de Nueva Caledonia, Pacífico Sudoccidental, con DESCRIPCIÓN DE UNA NUEVA ESPECIE. - Se han identificado doce especies de braquiópodos recientes que pertenecen a los géneros Lingula, Discradisca, Novocrania, Xenobrochus, Eucalathis, Frenulina, Argyrotheca, Campages, Thecidellina, y Lacazella a partir de muestras recogidas durante varios viajes de un barco de investigación francés, en aguas someras del área de Nueva Caledonia, Pacífico Sudoccidental. Seis de los géneros (Lingula, Xenobrochus, Eucalathis, Frenulina, Campages y Thecidellina) ya han sido registrados en la región de Nueva Caledonia mientras que cuatro de ellos (Discradisca, Novocrania, Argyrotheca y Lacazella) son registrados por primera vez en esta región. Además, Discradisca stella es el primer braquiópodo discínido reconocido en el área de Nueva Caledonia. Una de las especies descritas es nueva, Argyrotheca neocaledonensis $\mathrm{n}$. sp., de la familia Megathyrididae. También se discuten las afinidades biogeográficas de la fauna de estos braquiópodos de Nueva Caledonia.
\end{abstract}

Palabras clave: braquiópodos recientes, biogeografía, aguas someras, Nueva Caledonia, taxonomía, nueva especie.

\section{INTRODUCTION}

The New Caledonia exclusive economic zone (EEZ), situated between Australia and the Vanuatu archipelago, has one of the most intensively studied faunas in the southwest Pacific. Brachiopods from this region have mostly been collected from waters at more than 100 m depth (d'Hond, 1987; Laurin, 1992, 1997; Bitner et al., 2008b; Bitner, 2009) and until now only four species-two lingulides Lingula anatina Lamarck and $L$. adamsi Dall, a terebratulide Frenulina sangui- nolenta (Gmelin) and a thecideide Thecidellina maxilla (Hedley) - have been reported from waters shallower than $100 \mathrm{~m}$ (Emig, 1988; Bitner 2007a).

Between 1984 and 1989, within the French project "Lagon" 13 cruises were carried out in shallow waters around the largest island of New Caledonia, Grande Terre and around the Chesterfield atoll (Richer de Forges, 1991). The aim of this project was a large-scale geomorphological, sedimentological and faunistic study of each lagoon. The area of the study comprised $23400 \mathrm{~km}^{2}$ and was systematically dredged; $1217 \mathrm{sam}$ - 


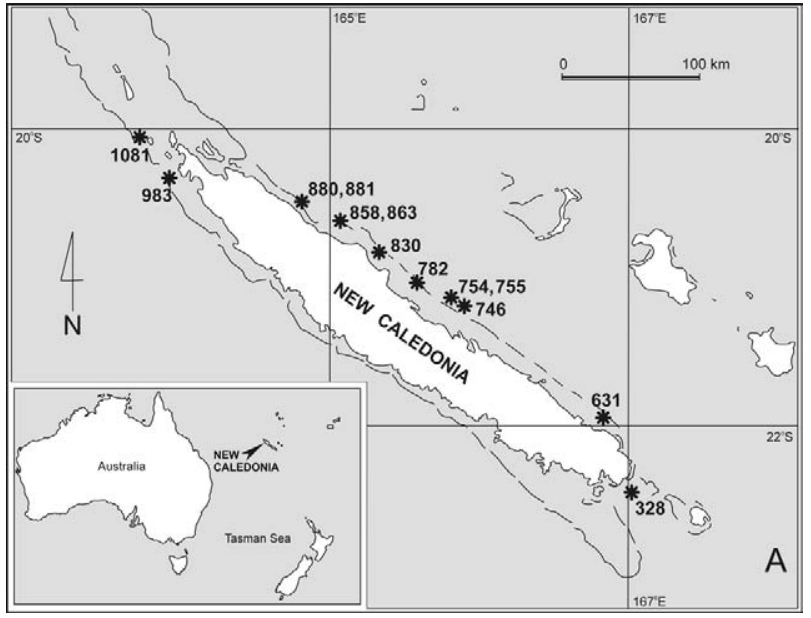

FIG. 1. - Map of New Caledonia, showing location of the dredging stations where brachiopods were found.

ples were collected, mostly from depths between 5 and $100 \mathrm{~m}$. Brachiopods were found at only 13 stations on the following five cruises-no. 6 in November 1984, no. 10 in August 1986, no. 11 in January 1987, no. 12 in April-May 1988, and no. 13 in October-November 1989 - carried out in the lagoon of the north, east and south coasts of New Caledonia (Fig. 1; see also Table 1). Only two stations contained more than one species, and only at station 830 were brachiopods rich in both specimens and species. The brachiopods are represented by either micromorphic or immature forms and all the material, except Lingula anatina, is clearly part of a death assemblage; some shells were filled with sediment.

In this report 12 species, including one new form, are described. The most interesting finds are the first records of the genera Discradisca, Novocrania, Argyrotheca, and Lacazella from the New Caledonian area.

The specimens described here are deposited in the collections of the Muséum national d'Histoire naturelle, Paris (NMHN BRA-3182-3210).

\section{SYSTEMATICS}

Phylum Brachiopoda Duméril, 1806 Subphylum Linguliformea Williams, Carlson, Brunton, Holmer and Popov, 1996

Class Lingulata Gorjansky and Popov, 1985

Order LINGULIDA Waagen, 1885

Superfamily Linguloidea Menke, 1828

Family LiNGULIDAE Menke, 1828

Genus Lingula Bruguière, 1797

Type species: Lingula anatina Lamarck, 1801.

Lingula anatina Lamarck, 1801 Fig. 2C

Lingula anatina Lamarck, 1801: Davidson, 1888: 206-215, pl. 29,
Figs. 1-8; Emig, 1982: 352-355, Fig. 9a-d; Emig, 1984: 171176, Figs. 2-4.

Lingula unguis (Linnaeus, 1758): Dall, 1920: 262-263; Hatai, 1940:

183-185, text-Fig. 18, pl. 8, Figs. 45-47; Zezina, 1985: 101. Lingula nipponica Hayasaka, 1931: Hatai, 1940: 181-183.

Material examined: New Caledonia, Secteur des Belep: stn 1081, 34 $\mathrm{m}$, two complete immature specimens.

Dimensions: Length $9.7 \mathrm{~mm}$, width $4.3 \mathrm{~mm}$.

Remarks. This species is very rare in the investigated material, being found only at one station. However, it was already recorded from New Caledonia (Emig, 1988; Bitner, 2007a). Lingula anatina is characterized by an elongate, oblong outline with subparallel lateral margins (Emig, 1982, 1984). The valve surface is smooth with distinct growth lines. The shell colour is slightly greenish to brownish along the posterior and lateral margins.

\section{Superfamily DiscinoIDEA Gray, 1840 \\ Family Discinidae Gray, 1840 \\ Genus Discradisca Stenzel, 1964}

Type species: Orbicula antillarum d'Orbigny, 1845.

\section{Discradisca stella (Gould, 1862)}

(Fig. 2A, B)

Discinisca stella (Gould, 1862): Dall, 1871: 41; Davidson, 1888: 204-205, pl. 26, Figs. 27, 30 (non 28, 29); Dall, 1920: 278; Thomson, 1927: 132; Hatai, 1940: 186-187; Zezina, 1985: 105; Harper, 1997: 240-243, pls. 1-6.

Material examined: New Caledonia, Secteur de Poindimié: stn 830 , $105-110 \mathrm{~m}$, one dorsal valve, slightly broken.

Remarks. The species Discinisca stella (Gould, 1862), with five other Discinisca species, was transferred to the genus Discradisca (Emig, 1997; see also Bitner et al., 2008a). The name Discradisca was first given as a subgenus of Discinisca to those species having fine, radial ribbed ornamentation (Stenzel, 1964). Later Cooper (1977) elevated Discradisca to generic level.

The studied material is very limited, consisting of only one dorsal valve. However, it is consistent with that hitherto described (Dall, 1871, 1920; Davidson, 1888; Hatai, 1940; Harper, 1997). The shell is small, up to $5.4 \mathrm{~mm}$ in valve length, nearly circular in outline, conical. The apex, situated subcentrally, is smooth, marked only by concentric growth lines (Fig. 2B). The shell surface is ornamented by numerous, fine radial costae and concentric growth lines.

In size and in its fine, ribbed ornamentation D. stella is close to D. indica (Dall, 1920) from the Indian Ocean. These two species differ, however, in the character of the ribs, which are distinctly granular and more widely spaced in D. indica (Cooper, 1973b; Bitner et al., 2008a).

So far D. stella has been identified from off Japan and China to northern Australia (Hatai, 1940; Richardson et al., 1989; Emig, 1997; Harper, 1997). The 
TABLE 1. - Locality data and species distribution among the stations.

\begin{tabular}{|c|c|c|c|}
\hline Station & Location & Depth & Species \\
\hline \multicolumn{4}{|l|}{ New Caledonia } \\
\hline \multicolumn{4}{|l|}{ Grand Récif Sud } \\
\hline Stn 328 & $22^{\circ} 27^{\prime} \mathrm{S}, 167^{\circ} 03^{\prime} \mathrm{E}$ & $72 \mathrm{~m}$ & Frenulina sanguinolenta \\
\hline \multicolumn{4}{|l|}{ Secteur de Yaté } \\
\hline Stn 631 & $21^{\circ} 58^{\prime} \mathrm{S}, 166^{\circ} 48^{\prime} \mathrm{E}$ & $43 \mathrm{~m}$ & Frenulina sanguinolenta \\
\hline \multicolumn{4}{|l|}{ Secteur de Canala } \\
\hline Stn 746 & $21^{\circ} 19^{\prime} \mathrm{S}, 165^{\circ} 54^{\prime} \mathrm{E}$ & $60 \mathrm{~m}$ & Frenulina sanguinolenta \\
\hline Stn 754 & $21^{\circ} 13^{\prime} \mathrm{S}, 165^{\circ} 49^{\prime} \mathrm{E}$ & $36 \mathrm{~m}$ & Frenulina sanguinolenta \\
\hline Stn 755 & $21^{\circ} 12^{\prime} \mathrm{S}, 165^{\circ} 48^{\prime} \mathrm{E}$ & $43 \mathrm{~m}$ & Frenulina sanguinolenta \\
\hline \multicolumn{4}{|l|}{ Secteur de Poindimié } \\
\hline Stn 782 & $21^{\circ} 06^{\prime} \mathrm{S}, 165^{\circ} 37^{\prime} \mathrm{E}$ & $30 \mathrm{~m}$ & Frenulina sanguinolenta \\
\hline \multirow[t]{11}{*}{ Stn 830} & $20^{\circ} 49^{\prime} \mathrm{S}, 165^{\circ} 19^{\prime} \mathrm{E}$ & $105-110 \mathrm{~m}$ & Discradisca stella \\
\hline & & & Novocrania reevei \\
\hline & & & Xenobrochus africanus \\
\hline & & & Eucalathis rugosa \\
\hline & & & Argyrotheca mayi \\
\hline & & & Argyrotheca neocaledonensis \\
\hline & & & Frenulina sanguinolenta \\
\hline & & & Campages mariae \\
\hline & & & Thecidellina maxilla \\
\hline & & & Thecidellina minuta \\
\hline & & & Lacazella sp. \\
\hline \multicolumn{4}{|l|}{ Grand Récif Mengalia } \\
\hline Stn 858 & $20^{\circ} 37^{\prime} \mathrm{S}, 165^{\circ} 07^{\prime} \mathrm{E}$ & $220 \mathrm{~m}$ & Frenulina sanguinolenta \\
\hline Stn 863 & $20^{\circ} 39^{\prime} \mathrm{S}, 165^{\circ} 07^{\prime} \mathrm{E}$ & $28 \mathrm{~m}$ & $\begin{array}{l}\text { Campages mariae } \\
\text { Erenuling sanouinolenta }\end{array}$ \\
\hline \multicolumn{4}{|l|}{ Secteur de Pouébo } \\
\hline Stn 880 & $20^{\circ} 30^{\prime} \mathrm{S}, 164^{\circ} 47^{\prime} \mathrm{E}$ & $30-52 \mathrm{~m}$ & Frenulina sanguinolenta \\
\hline Stn 881 & $20^{\circ} 29^{\prime} \mathrm{S}, 164^{\circ} 48^{\prime} \mathrm{E}$ & $27 \mathrm{~m}$ & Frenulina sanguinolenta \\
\hline \multicolumn{4}{|l|}{ Secteur de Poum } \\
\hline Stn 983 & $20^{\circ} 23^{\prime} \mathrm{S}, 163^{\circ} 57^{\prime} \mathrm{E}$ & $38-68 \mathrm{~m}$ & Frenulina sanguinolenta \\
\hline \multicolumn{4}{|l|}{ Secteur des Belep } \\
\hline Stn 1081 & $19^{\circ} 57^{\prime} \mathrm{S}, 163^{\circ} 43^{\prime} \mathrm{E}$ & $34 \mathrm{~m}$ & Lingula anatina \\
\hline
\end{tabular}

present finding from off New Caledonia extends the biogeographical range of this species southwards. This is the first record of a discinid from New Caledonia.

\section{Subphylum Cranifformea Popov, Bassett, Holmer and Laurie, 1993}

Class Craniata Williams, Carlson, Brunton, Homler and Popov, 1996

Order CRANIIDA Waagen, 1885

Superfamily CranioIdea Menke, 1828

Family CraniIDae Menke, 1828

Genus Novocrania Lee and Brunton, 2001

Type species: Patella anomala Müller, 1776.

\section{Novocrania reevei Lee and Brunton, 1986}

(Fig. 2D-K)

Crania Suessii Reeve, 1862: pl. 1, Fig. 2.

Novocrania sp.; Bitner, 2008: 424, Fig. 3A-C.

Material examined: New Caledonia, Secteur de Poindimié: stn 830, 60 dorsal valves.

Dimensions (in mm):

$\begin{array}{ccc}\text { Station number } & \text { Length } & \text { Width } \\ 830 & 6.0 & 6.7 \\ 830 & 5.6 & 5.9 \\ 830 & 5.5 & 6.2 \\ 830 & 4.7 & 5.9\end{array}$

Description. The material under study consists of only dorsal valves. Shell small (maximum length 6 $\mathrm{mm}$ ), thin, brownish and beige, subcircular with posterior margin nearly straight, wider than long. Dorsal valve conical, umbo subcentral, directed posteriorly. Shell surface rough, irregular, covered with randomly distributed pustules; growth lines concentric, numerous, fragmentary indistinct. Interiorly, width of the rim variable, usually narrow. Posterior adductor muscle scars large and rounded, widely separated, situated close to the hinge line. Anterior adductor muscle scars elevated on V-shaped, prominent ridges, nearly joined medianly, not reaching the margins; brachial retractor scars not separated from the adductors. Brachial protractor muscle scars prominent, elevated. No median ridge. In the anterior half of some valves mantle canals can be observed. Surface coarsely punctate.

Remarks. This poorly known species was originally described as Crania suessii by Reeve (1862) from off eastern Australia. As the name suessi was preoccupied by an Upper Cretaceous species of the same genus, Lee and Brunton (1986) proposed its replacement by reevei. However, they did not re-describe and/or re-illustrate the species. It is worth mentioning that the reproduction of Reeve's (1862) figure presented by Davidson (1888) shows the ribbed surface of Crania suessii $(=N$. reevei), which is not in accordance with the original figure, where only the colour pattern is indicated. 


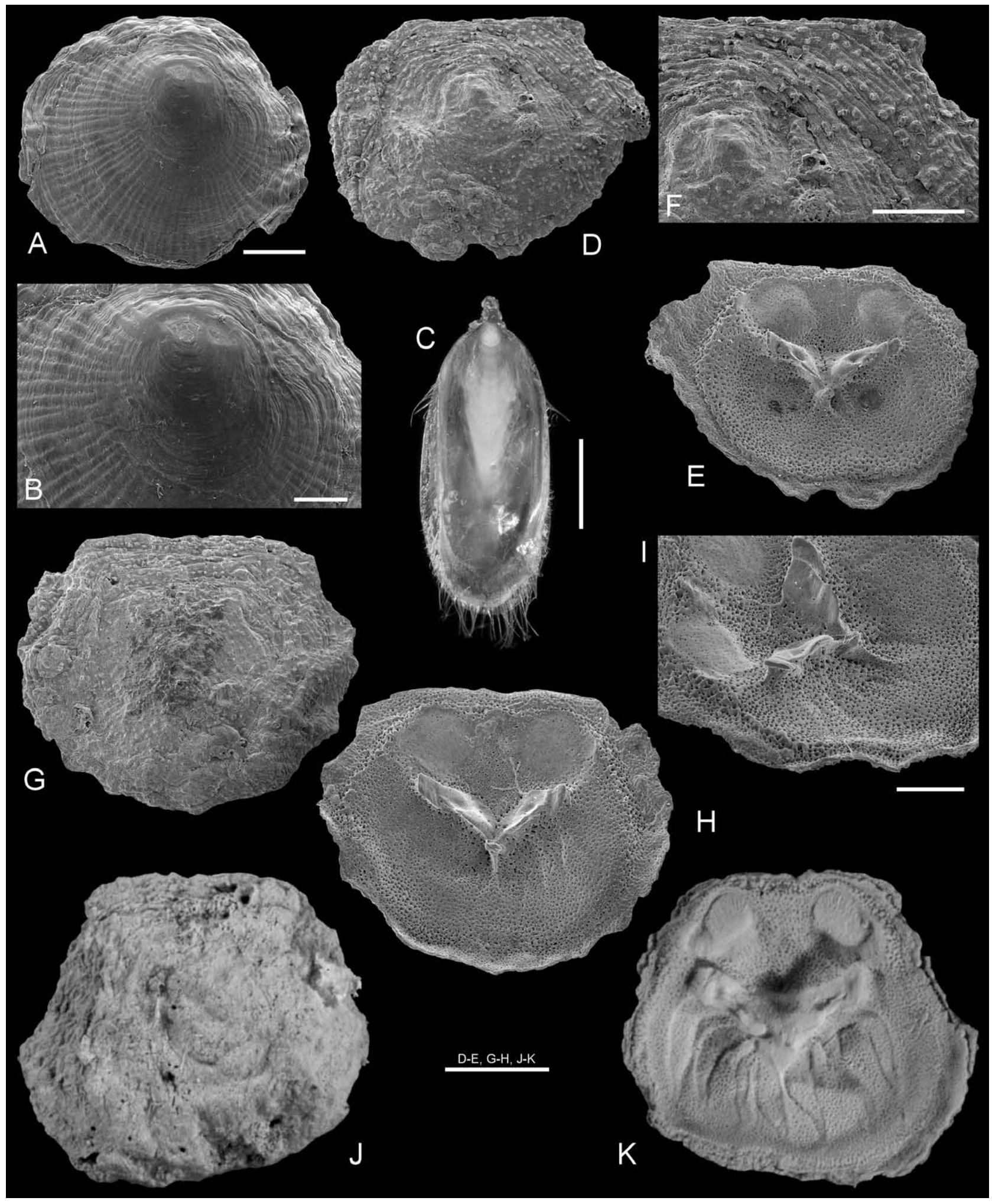

FIG. 2. - A, B, Discradisca stella (Gould, 1862), New Caledonia, stn 830, 105-110 m, SEM, exterior view of dorsal valve and enlargement (B) of the apex, MNHN BRA-3183. C, Lingula anatina Lamarck, 1801, New Caledonia, stn 1081, 34 m, MNHN BRA-3182. D-K, Novocrania reevei Lee and Brunton, 1986, New Caledonia, stn 830, 105-110 m, SEM; D-F, exterior and inner views of dorsal valve, and enlargement (F) of shell surface to show pustules, MNHN BRA-3185; G-H, exterior, inner and lateral views of dorsal valve, MNHN BRA-3186; J, K, exterior and inner views of dorsal valve, MNHN BRA-3184. Scale bars: A, F, I, 1mm, B, 500 um, C, 3 mm, D-E, G-H, J-K, 2 mm. 
The specimens described as Novocrania sp. from two nearby archipelagos, Fiji and Wallis and Futuna (Bitner, 2008), are consistent with the specimens investigated here, so they are included in synonymy of N. reevei.

Externally $N$. reevei is close to the Antarctic species $N$. lecointei (Joubin, 1901), which also has a finely pustulose surface (Foster, 1974). It differs, however, in being much smaller and having more distinct, elevated anterior adductor scars. Also, the specimen described by Cooper (1981) from south of Madagascar as Crania sp. has a pustulose exterior but its surface is smooth with regular growth lines (Cooper 1981: pl. 13, Fig. 4), not resembling that of $N$. reevei. Internally Crania sp. is readily distinguishable from the New Caledonian specimens in having much smaller posterior adductors and no elevated anterior adductor scars. The studied specimens are also similar externally to $N$. indonesiensis (Zezina, 1981a), but differ strongly internally; in $N$. indonesiensis muscle impressions are indistinct and differently arranged (Zezina, 1981a). N. reevei is easily distinguishable from the New Zealand species, $N$. huttoni (Thomson, 1916) by its shell ornamentation; in $N$. huttoni the shell surface is covered with radial ribs (Thomson, 1916; Lee, 1987).

In the lack of separation of the brachial retractor scars from the adductors, Novocrania reevei resembles N. turbinata (Poli, 1795) from the northeastern Atlantic and the Mediterranean (Logan and Long, 2001; Kroh et al., 2008). It differs, however, from $N$. turbinata in having a pustulose outer surface and much more elevated anterior adductor muscle scars. Additionally, $N$. turbinata is twice as large as $N$. reevei (Logan and Long, 2001). It is also worth noting that the presence of $N$. turbinata has been recently mentioned from the New Zealand region (MacFarlan et al., 2009).

From the New Caledonia region one more craniid species, Neoancistrocrania norfolki Laurin, 1992 has already been reported (Laurin, 1992, 1997; Bitner, 2009). This species is characterized by thick, massive valves, thus differing strongly from $N$. reevei. The two species also differ externally; in $N$. norfolki the shell surface is smooth without pustules. In turn, the presence of two erect processes on the dorsal valve in $N$. norfolki distinguishes this species internally from the specimens studied here.

Subphylum RHYNCHONELLIFORMEA Williams,

Carlson, Brunton, Holmer and Popov, 1996

Class Rhynchonellata Williams, Carlson, Brunton, Holmer and Popov, 1996

Order TeREBRATUlida Waagen, 1883

Suborder Terebratulidina Waagen, 1883

Superfamily DyscolioIDEA Fischer and Oehlert, 1890

Family DyscoliIDAE Fischer and Oehlert, 1890

Subfamily AEnigmathyridinaE Cooper, 1983 Genus Xenobrochus Cooper, 1981

Type species: Gryphus africanus Cooper, 1973b.

\section{Xenobrochus africanus (Cooper, 1973b)}

(Fig. 3D-G)

Gryphus africanus Cooper, 1973b: 8-9, pl. 4, Figs. 31-38.

Xenobrochus africanus: Cooper, 1981: 20, pl. 4, Figs. 30-35; Cooper, 1983: pl. 2, Figs. 20-23; Hiller, 1986: 111-112, Fig. 6; Laurin, 1997: 430-431, Figs. 15, 16.

Material examined: New Caledonia, Secteur de Poindimié: stn 830, $105-110 \mathrm{~m}, 3$ complete specimens, one ventral valve and fragmented dorsal valve.

Dimensions (in mm):

$\begin{array}{cccc}\text { Station number } & \text { Length } & \text { Width } & \text { Thickness } \\ 830 & 5.5 & 4.8 & - \\ 830 & 5.3 & 4.2 & 2.7 \\ 830 & 5.3 & 4.1 & 2.8\end{array}$

Remarks. Although the brachidium is not preserved, the studied specimens correspond very well to Xenobrochus africanus (Cooper, 1973b) in their small size, smooth surface, small mesothyrid foramen and wholly visible symphytium, and internally in lacking the cardinal process and having rudimentary hinge plates. This species was already reported from the New Caledonian region (Laurin, 1997), while from New Caledonia Laurin (1997) also described another species of Xenobrochus, X. indianensis (Cooper, 1973b) that differs strongly from $X$. africanus in having a prominent cardinal process and wider hinge plates. Recently Bitner (2009) recognized the species X. australis Cooper, 1981 in the material from the Norfolk Ridge that, like $X$. africanus, lacks the cardinal process but differs from the latter in having wide, triangular hinge plates (Bitner, 2009). X. africanus was originally described from the Indian Ocean (Cooper, 1973b, 1981, 1983; Hiller, 1986, 1994) and its occurrence in the New Caledonia region is the only Pacific occurrence so far reported.

Superfamily CANCELlothyridoIdea Thomson, 1926 Family Chlidonophoridae Muir-Wood, 1959

Subfamily Eucalathinae Muir-Wood, 1965

Genus Eucalathis Fischer and Oehlert, 1890

Type species: Terebratulina murrayi Davidson, 1878.

Eucalathis rugosa Cooper, 1973a (Fig. 3A-C)

Eucalathis rugosa Cooper, 1973a: 388-389, text-Fig. 2; pl. 43, Figs. 1-9; Zezina, 1985: 135; Zezina, 1987: 556; d'Hondt, 1987: 35; Laurin, 1997: 428-429, Figs. 13A-C, 14; Bitner, 2008: 434-437, Fig. 9; Bitner, 2009: 13, 7A.

Material examined: New Caledonia, Secteur de Poindimié: stn 830, $105-110 \mathrm{~m}, 152$ complete specimens, 26 ventral valves and 38 dorsal valves.

Dimensions (in mm):

$\begin{array}{cccc}\text { Station number } & \text { Length } & \text { Width } & \text { Thickness } \\ 830 & 4.0 & 3.7 & 2.3 \\ 830 & 3.7 & 3.1 & 2.1 \\ 830 & 3.3 & 3.1 & 1.9\end{array}$




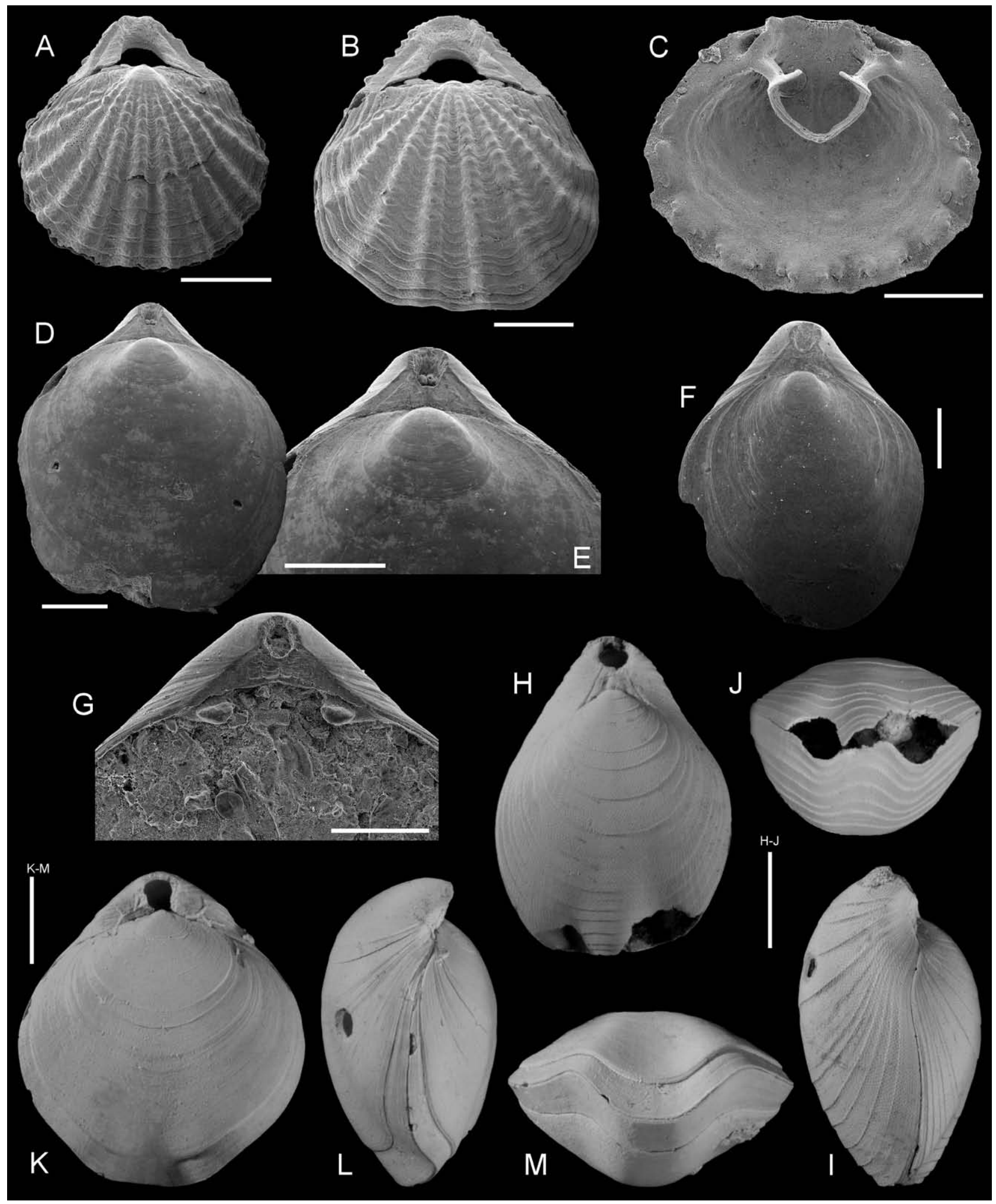

FIG. 3. - A-C, Eucalathis rugosa Cooper, 1973, SEM, New Caledonia, stn 830, 105-110 m; A, B, dorsal views of complete specimens, MNHN BRA-3190-3191; C, inner view of dorsal valve to show chlidonophorid brachidium, MNHN BRA-3192. D-G, Xenobrochus africanus (Cooper, 1973), New Caledonia, stn 830, 105-110 m, SEM; D, E, dorsal view of complete specimen and enlargement (E) of the posterior part, MNHN BRA-3187; F, dorsal view of complete specimen, MNHN BRA-3188; G, inner view of posterior part of ventral valve, MNHN BRA3189. H-J, Campages mariae (Adams, 1860), New Caledonia, stn 830, 105-110 m, dorsal, lateral and anterior views of complete specimen, MNHN BRA-3194. K-M, Frenulina sanguinolenta (Gmelin, 1791), New Caledonia, stn 830, 105-110 m, dorsal, lateral and anterior views of complete specimen, MNHN BRA-3193. Scale bars: A-G, 1mm, H-M, 3 mm. 
Remarks. This micromorphic species was already reported from the New Caledonian region (d'Hondt, 1987; Laurin, 1997; Bitner, 2009). It is characterized by the ornamentation of strong, single, coarse ribs. Its beak is relatively high with distinct beak ridges and a large, subtriangular foramen bordered by two small deltidial plates. The loop is short, with prominent but not united crural processes (Fig. 3C).

Originally E. rugosa was described from the Philippines (Cooper, 1973a). However it has a wide distribution in the western Pacific, from the southern Emperor Seamounts to Tasmania (Zezina, 1981b, c; Bitner, 2008), and it has also been recorded from the western part of the Indian Ocean (Zezina, 1987, 1994).

\section{Suborder Terebratellidina Muir-Wood, 1955 Superfamily LAQUEOIDEA Thomson, 1927 Family FrenUlinidae Hatai, 1938 Genus Frenulina Dall, 1895}

Type species: Anomia sanguinolenta Gmelin, 1791.

\section{Frenulina sanguinolenta (Gmelin, 1791)} (Fig. 3K-M)

Megerlia sanguinea; Davidson, 1887: 108-111, pl. 20, Figs. 1-8. Frenulina sanguinolenta; Dall, 1920: 336-337; Hatai, 1940: $327-$ 329, pl. 4, Figs. 42, 44-47, 49, 50, 52-54; Cooper, 1973b: 21-22, pl. 6, Figs. 1-3; pl. 8, Figs. 12-16; Zezina, 1985: 168; d'Hondt, 1987: 38; Laurin, 1997: 450-451, Fig. 47H-J; Bitner, 2006a 420-422, Figs. 2D-M, 3A-F; Bitner, 2006b: 28; Bitner, 2008: 439, Fig. 10C-G; Bitner, 2009: 16, 7F-H

Material examined: New Caledonia, Grand Récif Sud: stn 328, 72 m, one complete specimen; Secteur de Yaté: stn 631, 43 m, one complete specimen; Secteur de Canala: stn 746, 60 m, one complete specimen; stn 754, $36 \mathrm{~m}$, one complete specimen; stn 755, $43 \mathrm{~m}$, one complete specimen; Secteur de Poindimié: stn 782, 30 m, one complete specimen; stn 830, 105-110 m, 44 complete specimens, 5 ventral valves and 6 dorsal valves; Grand Récif Mengalia: stn 858, $220 \mathrm{~m}, 5$ complete specimens and one ventral valve; stn 863, $28 \mathrm{~m}$, one complete specimen; Secteur de Pouébo: stn 880, 30-52 m, 2 complete specimens; stn 881, 27 m, one complete specimen; Secteur de Poum: stn 983, 38-68 m, 3 complete specimens.

Dimensions (in mm):

$\begin{array}{cccc}\text { Station number } & \text { Length } & \text { Width } & \text { Thickness } \\ 782 & 6.3 & 6.1 & 3.3 \\ 830 & 10.2 & 9.1 & 5.8 \\ 858 & 10.8 & 10.9 & 6.1 \\ 983 & 11.0 & 10.1 & 5.4\end{array}$

Remarks. Frenulina sanguinolenta (Gmelin, 1791) is easily distinguishable by its small, sulcate shell, usually disjunct deltidial plates (Fig. 3K) and red colour pattern. The disjunct deltidial plates distinguish $F$. sanguinolenta from the Indian Ocean species, $F$. cruenta Cooper, $1973 \mathrm{~b}$ in which deltidial plates are always conjunct (Cooper, 1973b; Hiller, 1994). Those two species also differ in size, with $F$. cruenta being much larger, and in colour patterns. Internally, the difference is apparent as well; in $F$. sanguinolenta the inner hinge plates are developed whereas they are absent in $F$. cruenta.
It is one of the most widely distributed species in the western Pacific, being known from off Australia and China and from Japan to French Polynesia and Hawaii (Davidson, 1887; Dall, 1920; Thomson, 1918, 1927; Jackson and Stiasny, 1937; Hatai, 1940; Richardson, 1973a, b, 1979; Zezina, 1985; Emig, 1987; d'Hondt, 1987; Richardson et al., 1989; Saito, 1996; Laurin, 1997; Bitner, 2006a, b, 2007a, 2008, 2009). F. sanguinolenta, although not the most common in the investigated material, is most widespread, being found at 12 stations.

\section{Superfamily Megathyridoidea Dall, 1870 Family Megathyrididae Dall, 1870 Genus Argyrotheca Dall, 1900}

Type species: Terebratula cuneata Risso, 1826.

\section{Argyrotheca mayi Blochmann, 1913} Fig. 4H-J

Argyrotheca (Cistella) mayi Blochmann, 1913: 114, pl. 11, Figs. 10-11.

Argyrotheca mayi; Hiller et al., 2008: 171, Fig. 5A-H.

Material examined: New Caledonia, Secteur de Poindimié: stn 830, 105-110 m, 7 complete specimens.

Dimensions (in mm):

$\begin{array}{cccc}\text { Station number } & \text { Length } & \text { Width } & \text { Thickness } \\ 830 & 2.3 & 2.1 & 0.9 \\ 830 & 2.3 & 2.0 & 0.9 \\ 830 & 2.1 & 1.8 & 0.8\end{array}$

Remarks. The investigated specimens correspond well to those described and illustrated as Argyrotheca mayi Blochmann, 1913 from off South Australia and Tasmania (Hiller et al., 2008). The shell is very small, elongate triangular, smooth with distinct growth lines. The anterior commissure is rectimarginate. The hypothyrid foramen is large, triangular, bordered by two disjunct, narrow deltidial plates. The pedicle collar is wide, supported by a low, thin septum. A. mayi can be easily distinguished from a second New Caledonian Argyrotheca species, A. neocaledonensis n. sp. in having a triangular outline and narrow hinge line.

Recently Álvarez et al. (2008) erected a new genus Joania for those Argyrotheca species having a narrow hinge line, prominent cardinal process and tubercles on the inner valve margins. In the subtriangular outline and narrow hinge line A. mayi resembles the genus Joania but it differs in having a small cardinal process and lacking margin tubercles (Hiller et al., 2008: Fig. 5).

This is the first record of the genus Argyrotheca from the New Caledonian region.

Argyrotheca neocaledonensis $\mathrm{n}$. sp. (Fig. 4A-G)

Type material: Holotype: complete specimen MNHN BRA-3197, Fig. 4A,B. Paratype: open complete specimen MNHN BRA-3198, Fig. 4C-G. 


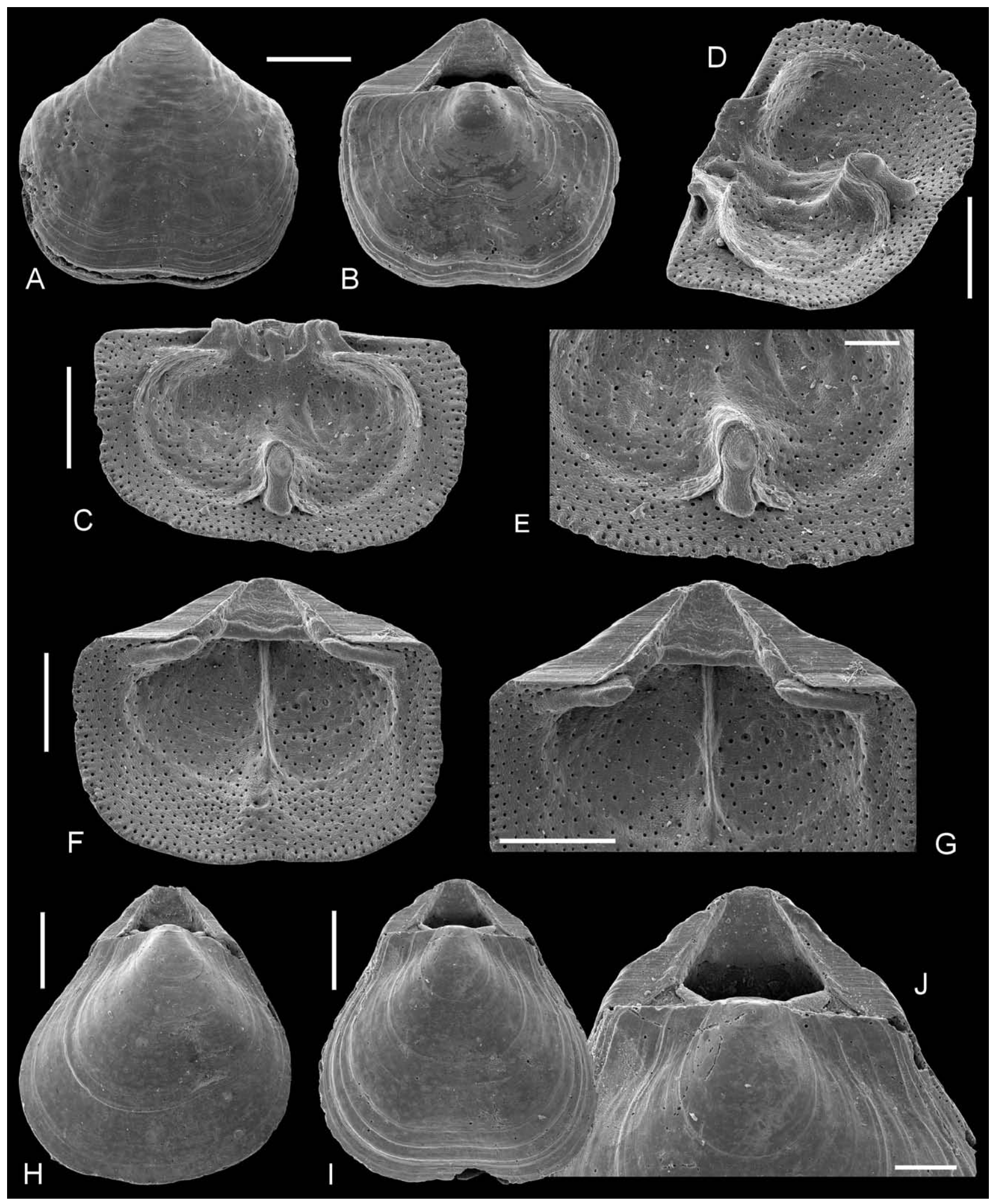

FIG. 4. - A-G, Argyrotheca neocaledonensis n. sp., New Caledonia, stn 830, 105-110 m; A, B, ventral and dorsal views of complete specimen, holotype, MNHN BRA-3197; C-G, paratype, MNHN BRA-3198, C-E, inner and lateral views of dorsal valve, and enlargement of the anterior fragment to show the loop attached to the septum, F, G, inner view of ventral valve and enlargement of the posterior part. H-J, Argyrotheca mayi Blochmann, 1913, New Caledonia, stn 830, 105-110 m; H, dorsal view of complete specimen, MNHN BRA-3195; I, J, MNHN BRA3196, dorsal view of complete specimen and enlargement of the posterior part. All SEM. Scale bars: A-D, F-I, $500 \mu \mathrm{m}$, E, J, $200 \mu \mathrm{m}$. 
Type locality: New Caledonia, Secteur de Poindimié, 2049'S $165^{\circ} 19^{\prime} \mathrm{E}, 105-110 \mathrm{~m}$.

Material examined: New Caledonia, Secteur de Poindimié: stn 830, two complete specimens.

Diagnosis: A very small, transversely subpentagonal Argyrotheca with smooth surface and wide hinge line; teeth wide, parallel to the hinge line.

Etymology: The species is named after New Caledonia, the type locality.

\begin{tabular}{cccc}
\multicolumn{2}{c}{ Dimensions (in mm): } & & \\
Specimen no. & Length & Width & Thickness \\
830 (holotype) & 1.9 & 1.9 & 1.0 \\
830 & 1.8 & 2.1 & -
\end{tabular}

Description. Shell very small, subpentagonal in outline, ventribiconvex. Shell surface smooth with distinct growth lines. Shell coarsely punctate. Hinge line wide, straight, nearly equal to maximum width. Shallow sulcus on both valves. Anterior commissure rectimarginate. Beak high with sharp beak ridges. Interarea well developed. Foramen very large, triangular, hypothyrid, bordered by two narrow deltidial plates.

Ventral valve interior with short wide teeth lying parallel to the hinge line. Pedicle collar wide, excavated anteriorly, supported by median septum that extends to $2 / 3$ of the valve length. Dorsal valve interior with high inner socket ridges and prominent cardinal process. Crura thick, very short; crural processes short. Descending branches unite valve floor posteriorly and reappear anteriorly to overgrow the septum. Median septum triangular in profile, short but high with 2 serrations. Muscle scars distinct on both valves, marked as suboval depressions.

Remarks. Specimens of the genus Argyrotheca are very rare in the Pacific, but so far those described belong to three species. The studied specimens are close in outline to A. australis (Blochmann, 1910). They differ, however, from this South Australian species in having a smooth surface and internally in having wide teeth; the teeth in A. australis are hooked (Hiller et al., 2008). From A. mayi the discussed specimens differ in outline; $A$. mayi has an elongate triangular outline with a short hinge margin (Hiller et al., 2008). Also teeth in A. neocaledonensis and A. mayi display a strong difference, being short and wide in the former, and hooked in the latter.

The investigated specimens are easily distinguishable from A. arguta Grant, 1983 from Bikini Atoll in lacking tubercles on the inner margin (Cooper, 1954; Grant, 1983). Also the specimens from Fiji described as Argyrotheca sp. (Bitner, 2008) posses tubercles on the valve margin that clearly distinguishes them from A. neocaledonensis $\mathrm{n}$. sp. The presence of tubercles and a distinct cardinal process in A. arguta and Argyrotheca sp. from Fiji may indicate that those species should better be placed in the newly created genus Joania Álvarez, et al., 2008.

Superfamily Terebratelloidea King, 1850 Family DaLlinidae Beecher, 1893

Subfamily NipPONITHYRIDINAE Hatai, 1938 Genus Campages Hedley, 1905

Type species. Campages furcifera Hedley, 1905.

Campages mariae (Adams, 1860)

(Fig. 3H-J)

Campages basilanica Dall, 1920: 365; Thomson, 1927: 250; Hatai, 1940: 309, pl. 5, Figs. 68-72.

Campages mariae (Adams, 1860): Cooper, 1970: 900, pl. 129, Figs. 19-30; Bitner, 2009: 16-17, Fig. 11A-G.

Material examined: New Caledonia, Secteur de Poindimié: stn 830, 105-110 m, one complete immature specimen; Grand Récif Mengalia: stn $858,220 \mathrm{~m}$, one complete immature specimen.

Dimensions (in mm):

$\begin{array}{cccc}\text { Station number } & \text { Length } & \text { Width } & \text { Thickness } \\ 830 & 9.5 & 7.0 & 5.4 \\ 858 & 8.9 & 6.6 & 5.0\end{array}$

Remarks. This species has already been reported from the New Caledonia region (Bitner, 2009). It is characterized by distinct growth lines and a folded anterior commissure (Cooper, 1970). The investigated specimens are immature, as shown by their small size and large foramen. C. mariae is restricted to the western Pacific (Hatai, 1940; Richardson et al., 1989; Logan, 2007; Bitner, 2009).

Order THECIDEIDA Elliott, 1958

Superfamily THECIDEOIDEA Gray, 1840

Family THECIDELLINIDAE Elliott, 1958

Subfamily TheCIDELlininae Elliott, 1953

Genus Thecidellina Thomson, 1915

Type species: Thecidium barretti Davidson, 1864.

Thecidellina maxilla (Hedley, 1899)

(Fig. 5G-J)

Thecidea maxilla Hedley, 1899: 508-510, Fig. 57.

Thecidellina maxilla; Dall, 1920: 283; Thomson, 1927: 140; Cooper, 1954: 317, pl. 81, Figs 1-10; Zezina, 1985: 208; Laurin, 1997: 453-454, Fig. 40A-B; Lee and Robinson, 2003: 350-352, Figs. 28-35; Bitner, 2007b: 498-499, Fig. 3A-H; Bitner, 2008: 451, Fig. 19A-C. Bitner, 2009: 17-18, Fig. 12A-J.

Material examined: New Caledonia, Secteur de Poindimié: stn 830, $105-110 \mathrm{~m}, 338$ complete specimens, 46 ventral valves, 172 dorsal valves.

Dimensions (in mm):

$\begin{array}{cccc}\text { Station number } & \text { Length } & \text { Width } & \text { Thickness } \\ 830 & 5.6 & 3.7 & 3.1 \\ 830 & 5.3 & 3.5 & - \\ 830 & 4.6 & 3.2 & 2.5\end{array}$




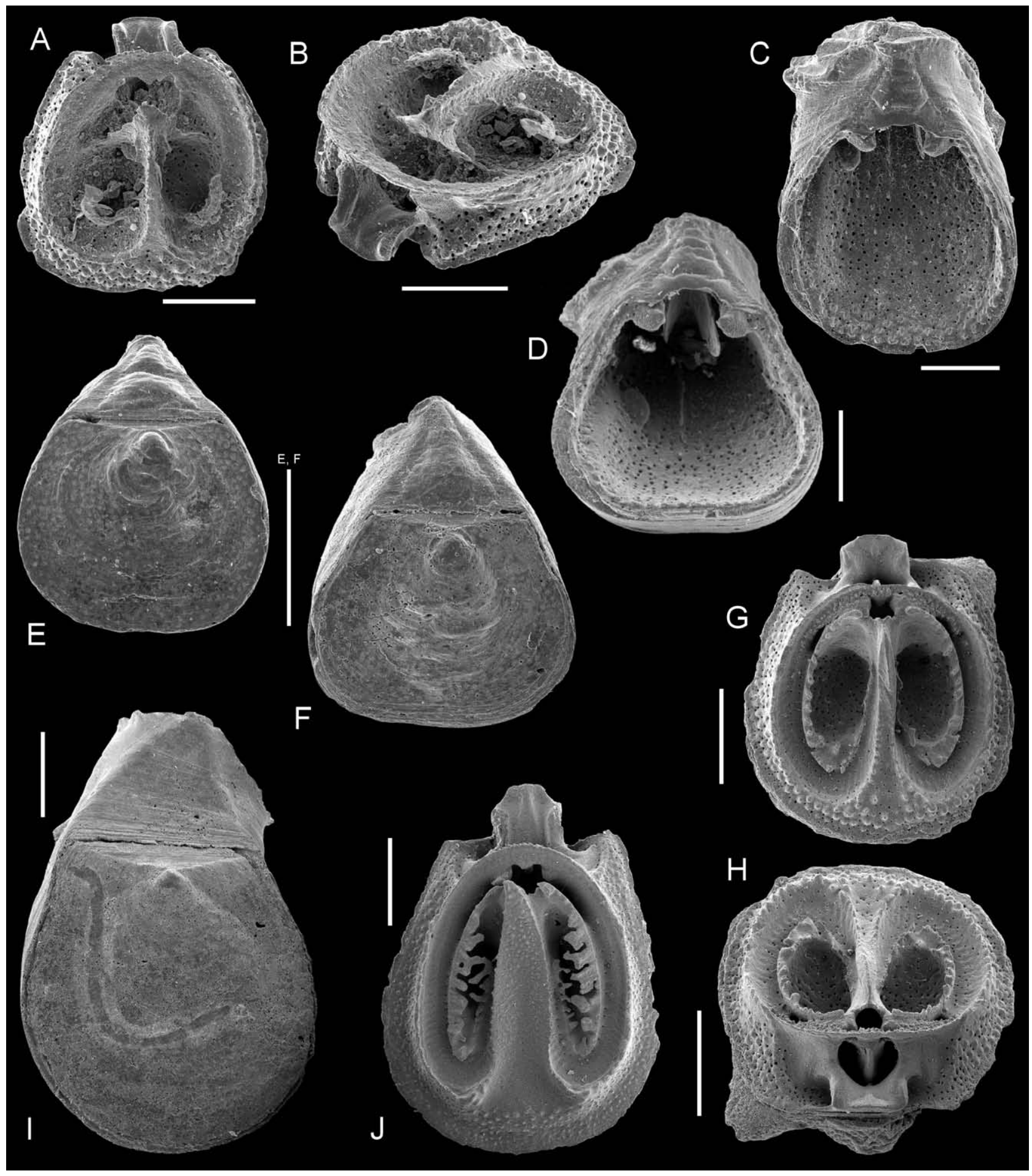

FIG. 5. - A-F, Thecidellina minuta Cooper, 1981, New Caledonia, stn 830, 105-110 m; A,B, inner and lateral views of dorsal valve, MNHN BRA-3199; C, D, inner view of ventral valve and titled enlargement to show hemispondylium, MNHN BRA-3200; E, F, dorsal views of complete specimens, MNHN BRA-3201-3202. G-J, Thecidellina maxilla (Hedley, 1899), New Caledonia, stn 830, 105-110 m; G, H, inner and posterior views of dorsal valve, MNHN BRA-3203; I, dorsal view of complete specimen, MNHN BRA-3204; J, inner view of dorsal valve, MNHN BRA-3205. All SEM. Scale bars: A-D, $500 \mu \mathrm{m}, \mathrm{E}-\mathrm{J}, 1 \mathrm{~mm}$.

Remarks. Although found only in one sample, Thecidellina maxilla (Hedley, 1899) is the most common species in the investigated material, more than
500 specimens having been recovered. T. maxilla was already recorded from the New Caledonian region (Laurin, 1997; Bitner, 2007a, 2009) and is widely dis- 


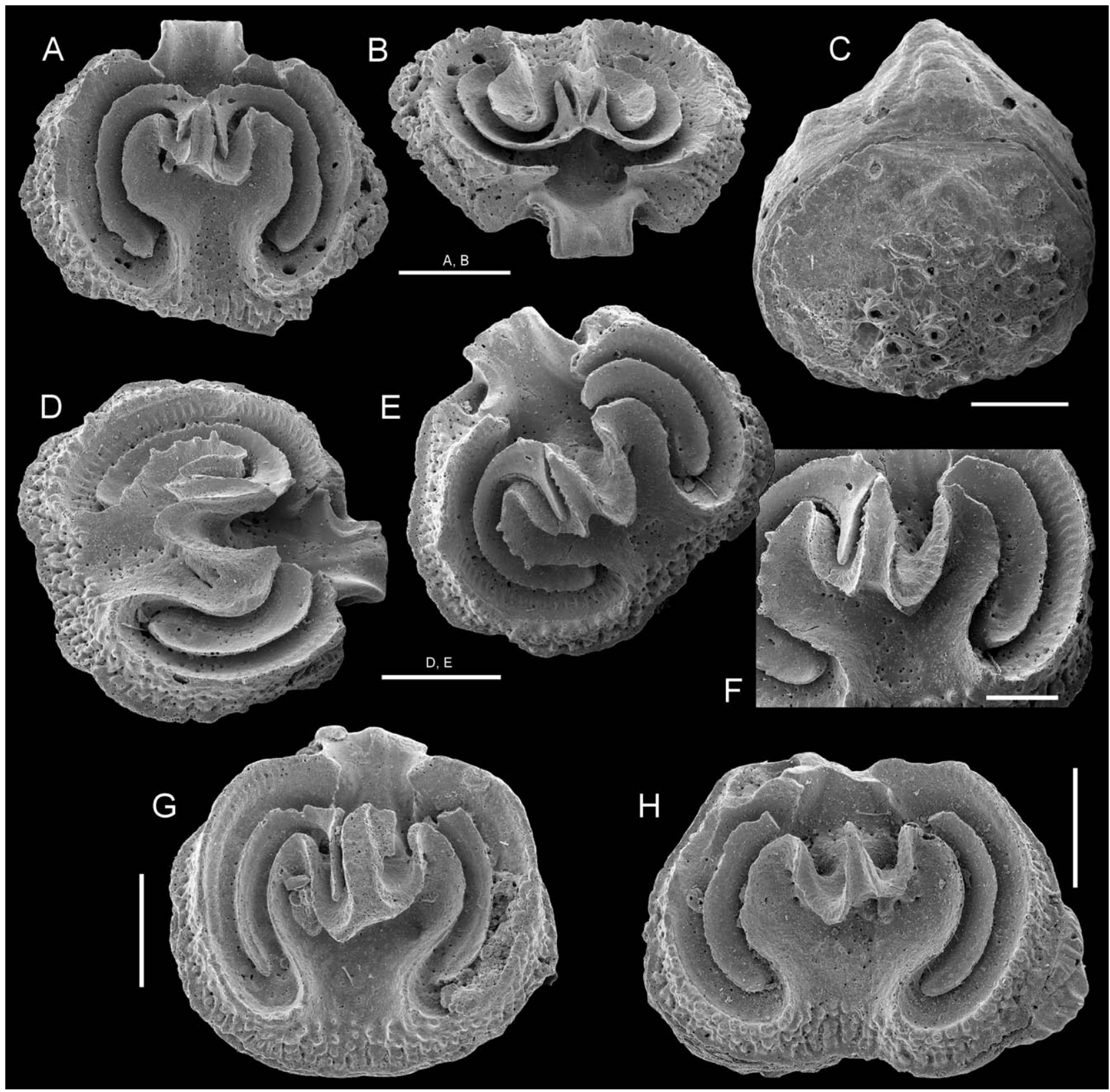

FIG. 6. - Lacazella sp., New Caledonia, stn 830, 105-110 m; A, B, inner and posterior views of dorsal valve, MNHN BRA-3206; C, dorsal view of complete specimen, MNHN BRA-3207; D-F, lateral views of dorsal valve and enlargement (F) of the trifurcating median ramusramuli complex; MNHN BRA-3208; G, H, inner views of dorsal valves, MNH BRA-3209-3210. All SEM. Scale bars: A-E, G, H, 1 mm, $\mathrm{F}, 500 \mu \mathrm{m}$.

tributed in the western and central Pacific (Thomson, 1927; Cooper, 1954; Pajaud, 1970; Zezina, 1985; Lee and Robinson, 2003; Bitner, 2007b, 2008; MacFarlan et al., 2009).

\section{Thecidellina minuta Cooper, 1981} (Fig. 5A-F)

Thecidellina minuta Cooper, 1981: 61-62, pl. 6, Figs. 27-40; Zezina, 1994: 50, Fig. 3; Lee and Robinson, 2003: 355; Bitner, 2009 18, Fig. 13A-I.
Material examined: New Caledonia, Secteur de Poindimié: stn 830, $105-110 \mathrm{~m}, 12$ complete specimens and 2 ventral valves.

Dimensions (in mm):

$\begin{array}{cccc}\text { Station number } & \text { Length } & \text { Width } & \text { Thickness } \\ 830 & 2.3 & 1.6 & - \\ 830 & 2.2 & 1.7 & 1.2 \\ 830 & 1.9 & 1.5 & 0.9\end{array}$

Remarks. In their small size and the presence of an upraised triangular pseudodeltidium the investi- 
gated specimens closely resemble Thecidellina minuta Cooper, 1981. Canopying spicules are usually well developed in T. minuta (compare Cooper, 1981; Zezina, 1994; Bitner, 2009) but in the one open, complete specimen no interconnected canopying spicules covering brachial cavities are visible (Fig. 5A, B). This may, however, result from its poor state of preservation. The prongs of the hemispondylium form two thin plates (Fig. 5D). T. minuta was originally described from the Indian Ocean (Cooper, 1981) but recently this species was recognized in the material from the Norfolk Ridge, to the south of New Caledonia (Bitner, 2009). It has also been identified from the Red Sea (A. Logan, pers. comm.)

Family THECIDEIDAE Gray, 1840

Subfamily LACAZELLINAE Backhaus, 1959

Genus Lacazella Munier-Chalmas, 1880

Type species: Thecidea mediterranea Risso, 1826.

\section{Lacazella sp.}

(Fig. 6A-H)

Material examined: New Caledonia, Secteur de Poindimié: stn 830, 105-110 m, one complete specimen and 6 dorsal valves.

\section{Dimensions: Length $4.0 \mathrm{~mm}$, width $3.7 \mathrm{~mm}$.}

Description. Shell small, subtriangular, ventriconvex, dorsal valve nearly flat, transversely oval, wider than long. Shell surface irregular, growth lines visible. Interarea with upraised triangular pseudodeltidium (Fig. 6C). Hinge line straight. Anterior commissure rectimarginate. Cardinal process prominent, slightly trilobed. Rim papillose. Bridge broken in all specimens. Median septum divided to form a trifurcating structure consisting of a pair of crescentic lateral ramuli and a median ramus which ends posteriorly in a pointed lobe. (Fig. 6A, F). Median depression wide. Two major (outer) interbrachial lobes well defined. Two minor (inner) lobes slightly divergent and interdigitating with posterior part of median ramus. Margins of interbrachial lobes smooth.

Remarks. The material is represented by the dead shells, rather poorly preserved. The articulated specimen with pseudodeltidium represents most probably the genus Lacazella but all attempts to open the shell failed, precluding examination of dorsal and ventral valve interiors. None of the dorsal valves is completely preserved, so not all the characters can be observed. In consequence, specific determination of this material is not possible.

This is the first description of Lacazella from the Pacific Ocean and the first record of this genus from the New Caledonian region. However, the presence of an undescribed Lacazella species in submarine caves of Okinawa, Japan has been mentioned by Saito et al . (2000) and by Motchurova-Dekova et al. (2002).
To date, three extant species of Lacazella have been described (Logan, 2007). The type species, L. mediterranea (Risso, 1826) from the Mediterraneam Sea (Logan, 1979; Âlvarez and Emig, 2005) is regarded as neoendemic to the Mediterranean (Logan et al., 2004). It differs from the New Caledonian Lacazella sp. in having denticulated ascending lobes. The only Indian Ocean species, L. mauritiana Dall, 1920 is very similar to L. mediterranea (Cooper, 1973b: pl. 1, Figs. 7-9) in having denticulated lobes, thus differing from Lacazella sp. described here. In turn, L. caribbeanensis Cooper, 1977 from the Caribbean Sea like the investigated specimens, has smooth margins to its ascending elements (Cooper, 1977). L. mediterranea, L. mauritiana and $L$. caribbeanensis also differ from each other in the internal features of the ventral valve, which was not available for study in the present material.

\section{DISCUSSION}

To date, very little has been known about the shallow-water brachiopods of the New Caledonian region (Emig, 1988; Bitner, 2007a), though more is known about the deep-sea benthic communities. The brachiopod collection described here was obtained from the shallow waters around the main island of New Caledonia. It consists of 12 species belonging to 10 genera: Lingula anatina Lamarck, Discradisca stella (Gould), Novocrania reevei Lee and Brunton, Xenobrochus africanus (Cooper), Eucalathis rugosa Cooper, Frenulina sanguinolenta (Gmelin), Argyrotheca mayi Blochmann, A. neocaledonensis n. sp., Campages mariae (Adams), Thecidellina maxilla (Hedley), T. minuta Cooper, and Lacazella sp. Six of them, X. africanus, E. rugosa, $F$. sanguinolenta, $C$. mariae, T. maxilla, and T. minuta, were also reported from deep water in the New Caledonian region (Laurin, 1997; Bitner, 2009) while L. anatina is known only from shallow water (Emig, 1988; Bitner, 2007a). Five species are reported for the first time from the New Caledonian region.

Discradisca stella is not only the first record of the genus and species but also the first record of discinid brachiopods in the New Caledonian region. Also $N$. reevei represents the first record of the genus Novocrania from New Caledonian waters. This species was originally described from off eastern Australia (Reeve, 1862). It has been also earlier reported from off Fiji, but because of the limited material it was described in open nomenclature (Bitner, 2008).

Most interesting is the finding of two megathyridid species, Argyrotheca mayi and A. neocaledonensis, and a thecideide, Lacazella sp. Both genera represent the first records in the studied area. Argyrotheca is a very rare genus in the Pacific (Cooper, 1954; Grant, 1983; Bitner, 2008; Hiller et al., 2008), being known from off Australia, the Marshall Islands and Fiji. However, at least two species of Argyrotheca were reported from the submarine caves in the Ry- 
ukyu Islands, Japan (Saito et al., 2000); the material has never been taxonomically described. The genus Lacazella was also recorded, but not described, from the submarine caves of Japan (Saito et al., 2000). In this report Lacazella is for the first time described and illustrated from the Pacific Ocean. In the Pacific two species of another lacazelline genus, Ospreyella, have been reported: $O$. depressa Lüter from the Great Barrier Reef of Australia and O. palauensis Logan from Palau, northwestern Pacific (Lüter et al., 2003; Logan, 2008).

Some investigated brachiopod specimens show evidence of gastropod predation activity. The highest frequency of drill holes is observed in Frenulina sanguinolenta and Eucalathis rugosa, where 24 (32.4\%) and $17(7.9 \%)$ specimens, respectively were drilled. No predation activity was observed in the cementing forms Novocrania reevei, Thecidellina species and Lacazella sp., or on either species of Argyrotheca.

With 5 species reported in the present study for the first time from New Caledonia, the total number of species from this region increases to 43 (d'Hondt, 1987; Emig, 1988; Laurin, 1997; Bitner, 2007a, 2009; Bitner et al., 2008b), exceeding the New Zealand region, where 40 species are recorded (MacFarlan et al., 2009). The New Caledonian brachiopod fauna shows the greatest affinity to the fauna from Fiji, sharing 15 genera and 11 species (Bitner, 2006b, 2008). Due to the new discovery of Discradisca, Novocrania and Argyrotheca, the number of common genera and species with Australia and New Zealand increases to 12 genera and 7 species in Australia and 12 genera and 6 species in New Zealand. Also, earlier studies showed closer affinities between New Caledonian and Fijian faunas than between New Caledonian and Australian and New Zealand faunas (Bitner, 2009), although today's surface current system would rather suggest affinities between New Caledonia and Australia. Such a pattern may be better understood in the light of the geological history of this region. In the early Tertiary New Caledonia and Fiji were geographically closer than today (Johnston, 2004: Fig. 5), suggesting easy exchange of faunas. In the Middle Miocene, clockwise rotation of the Vanuatu arc caused the shifting of Fiji to the east, separating New Caledonia and Fiji from each other. The biogeographical pattern of brachiopod distribution in the South-West Pacific is more readily explained by vicariance (Humphries and Ebach, 2004; Heads, 2009), when geological processes such as plate tectonics led to separation of regions and their faunas, than by simple dispersal (see also Bitner, 2009).

Technical limitations in collecting shallow-water faunas caused undersampling of such areas around New Caledonia (see Richer de Forges, 1991: p. 17), so it is probable that further investigations could increase the number of shallow-water brachiopod species from this region. In particular, cryptic habitats are potentially a good source of new forms.

\section{ACKNOWLEDGEMENTS}

The material was collected by Dr. B. Richer de Forges (IRD, Nouméa), to whom I am very grateful. Part of the work was done under the financial and logistic support of the European Commission's Research Infrastructure Action via the SYNTHESYS Project FR-TAF-3438, enabling me to visit the Muséum national d'Histoire naturelle, Paris; Prof. P. Bouchet and Dr. P. Lozouet are thanked for their help in accessing the brachiopod collections and providing facilities there. I am thankful to Prof. A. Logan (University of New Brunswick, Saint John) for helpful comments on thecideide brachiopods and for sending comparative material; Prof. Logan also reviewed the paper, providing several suggestions that improved it. I am grateful to Dr. J. Robinson (University of Otago, Dunedin) for valuable discussion on the craniids and comparative material of Novocrania reevei. I express my sincere thanks to Dr. B.L. Cohen (University of Glasgow, Glasgow) for reading the early version of the manuscript, providing valuable comments and improving the language. I am very grateful to Dr. B. Kremer (Institute of Paleobiology, Warszawa) for help with the Spanish abstract. Ms A. Hołda-Michalska (Institute of Paleobiology, Warszawa) helped in the preparation of Figure 1. The macrophotographs were taken by Ms G. Dziewińska (Institute of Paleobiology, Warszawa). The SEM micrographs were taken in the SEM laboratory of the Institute of Paleobiology (Warszawa) using a Philips XL-20 scanning microscope.

\section{REFERENCES}

Álvarez, F. and C.C. Emig. - 2005. Brachiopoda. In: F. Álvarez, C.C. Emig, C. Roldán and J. M. Viéitez,. M.A. Ramos et al. (eds.). Lophophorata, Phoronida, Brachiopoda. Museo Nacional de Ciencias Naturales, CSIC, Madrid: Fauna Ibérica, 27: 57-177.

Álvarez, F., C.H.C. Brunton and S.L. Long. - 2008. Loop ultrastructure and development in recent Megathiridoidea, with description of a new genus, Joania (type species Terebratula cordata Risso, 1826). In: M. Cusack and D.A.T. Harper (eds.), Brachiopod Research into the Third Millennium. Trans. R. Soc. Edinburgh Earth Environ. Sc., 98: 391-403.

Bitner, M.A. - 2006a. The first record of brachiopods from the Marquesas Islands, French Polynesia, south-central Pacific. Pac. Sc., 60: 417-424.

Bitner, M.A. - 2006b. Recent brachiopods from the Fiji and Wallis and Futuna Islands, Southwest Pacific. In: J.L. Justine and B. Richer de Forges (eds.), Tropical Deep Sea Benthos 24. Mém. Mus. nat. Hist. natur., 193: 15-32.

Bitner, M.A. - 2007a. Shallow water brachiopod species of New Caledonia. In: C. Payri and B. Richer de Forges (eds.), Compedium of marine species of New Caledonia. Doc. Sci. Techn., 117, Vol. spécial. IRD: Nouméa.

Bitner, M.A. - 2007b. Recent brachiopods from the Austral Islands, French Polynesia, South-Central Pacific. Zoosystema, 29: 491-502.

Bitner, M.A. - 2008. New data on the Recent brachiopods from the Fiji and Wallis and Futuna islands, South-West Pacific. Zoosystema, 30: 419-461.

Bitner, M.A. - 2009. Recent Brachiopoda from the Norfolk Ridge, New Caledonia, with description of four new species. Zootaxa, 2235: 1-39.

Bitner, M.A., A. Logan and E. Gischler. - 2008a. Recent brachio- 
pods from the Persian Gulf and biogeographical significance. Sci. Mar., 72: 279-285.

Bitner, M.A., B.L.Cohen, S.L. Long, B. Richer de Forges and M. Saito. - 2008b. Gyrothyris williamsi sp. nov. and inter-relationships of some taxa from waters around New Zealand and the southern oceans (Rhynchonelliformea: Terebratelloidea). In: M. Cusack and D.A.T. Harper (eds.), Brachiopod Research into the Third Millenium. Trans. R. Soc. Edinburgh Earth Environ. Sc. 98: 425-435.

Blochmann, F. - 1913. Some Australian brachiopods. Pap. Proc. R. Soc. Tasman., 1913: 112-115.

Cooper, G.A. - 1954. Recent brachiopods. Bikini and Nearby Atolls, Marshall Islands. Geol. Surv. Prof. Paper, 260-G: 315-318.

Cooper, G.A. - 1970. Brachiopoda: Japanithyris is Campages. J. Paleontol., 44: 898-904.

Cooper G. A. - 1973a. Fossil and Recent Cancellothyridacea (Brachiopoda). Sci. Rep. Tohoku Univ., second ser. (Geol.), Special Volume (Hatai Memorial Volume), 6: 371-390.

Cooper, G.A. - 1973b. New Brachiopoda from the Indian Ocean. Smithson. Contrib. Paleobiol., 16: 1-45.

Cooper, G.A. - 1977. Brachiopods from the Caribbean Sea and adjacent waters. Stud. Trop. Ocean., 14: 1-211.

Cooper, G.A. - 1981. Brachiopods from the Southern Indian Ocean (Recent). Smiths. Contrib. Paleobiol., 43: 1-93.

Cooper, G.A. - 1983. The Terebratulacea (Brachiopoda), Triassic to Recent: a study of the brachidia (loops). Smiths. Contrib. Paleobiol., 50: 1-445.

Dall, W.H. - 1871. Report on the Brachiopoda obtained by the United States Coast Survey Expedition, in Charge of L.F. de Pourtalès, with a revision of the Craniidae and Discinidae. Bull. Mus. Comp. Zool. (Harvard), 3: 1-45.

Dall, W.H. - 1920. Annoted list of the Recent Brachiopoda in the collection of the United States National Museum, with description of thirty-three new forms. Proc. U. S. Nat. Mus., 57: 261-377.

Davidson, T. - 1886-1888. A monograph of Recent Brachiopoda. Part I-III. Trans. Linn. Soc. Lond., second ser., 4 (Zool.): 1-248.

Emig, C.C. - 1982. Taxonomie du genre Lingula (Brachiopodes, Inarticulés). Bull. natn. Mus. Hist. nat., Paris, 4A (3-4): 337-367.

Emig C.C. - 1984. Lingula anatina Lamarck from Mutsu Bay, Northern Japan. Bull. mar. biol. St. Asamushi, Tôhoku Univ., 17: $171-176$

Emig, C.C. - 1987. Phylum Brachiopoda. In: D.M. Devany and L.G. Eldredge (eds.), Reef and shore fauna of Hawaii. Section 2: Platyhelminthes through Phoronida and Section 3: Sipuncula through Annelida. Bishop Mus. Spec. Publ., 64: 167-170.

Emig, C.C. - 1988. Les Brachiopodes actuels sont-ils des indicateurs (paléo) bathymétriques? Géol. Mediterr., 15: 65-71.

Emig, C.C. - 1997. Biogeography of inarticulated brachiopods. In: R.L. Kaesler (ed.), Treatise on invertebrate Paleontology. Part H. Brachiopoda Revised. Geological Society of America and University of Kansas. Boulder, Colorado and Lawrence, Kansas, 1: 497-502.

Foster, M.W. - 1974. Recent Antarctic and Subantarctic brachiopods. Antarct. Res. Ser., 21: 1-189.

Grant, R.E. - 1983. Argyrotheca arguta, a new species of brachiopod from the Marshall Islands, Western Pacific. Proc. Biol. Soc. Wash., 96: 178-180.

Harper, E. - 1997. Discinisca stella (Gould, 1860): an intertidal inarticulate brachiopod from the Cape d'Aguilar Marine Reserve, Hong Kong. In: B. Morton (ed.), The Marine Flora and Fauna of Hong Kong and Southern China IV. Proc. Eighth Int. Mar. Biol. Workshop: The Marine Flora and Fauna of Hong Kong and Southern China, Hong Kong University Press, Hong Kong, 235-248.

Hatai, K.M. - 1940. The Cenozoic Brachiopoda from Japan. Sci. Rep. Tohoku Imper. Univ., Sendai, Japan, Second Series (Geol.), 20: 1-413.

Heads, M. - 2009. Vicariance. In: R.G. Gillespie and D.A. Clague (eds.), Encyclopedia of Islands, pp. 947-950. University of California Press, Berkeley.

Hedley, C. - 1899. Mollusca of Funafuti, part 2, Pelecypoda and Brachiopoda. Mem. Austral. Mus., 3: 508-510.

Hiller, N. - 1986. The South African Museum's Meiring Naude cruises. Part 16. Brachiopoda from the 1975-1979 cruises. Ann. S. Afr. Mus., 97: 97-140.

Hiller, N. - 1994. The environment, biogeography, and origin of the southern African Recent brachiopod fauna. J. Paleontol., 68: 776-786.

Hiller, N., J.H. Robinson and D.E. Lee. - 2008. The micromorphic brachiopod Argyrotheca (Terebratulida: Megathyridoidea) in Australia and New Zealand. Proc. R. Soc. Vic., 120: 167-183.

d'Hondt, J-L. - 1987. Observations sur les Brachiopodes actuels de Nouvelle-Calédonie et d'autres localités de l'Indo-Pacifique. Bull. Mus. nat. Hist. natur., série 4, 9, section A (1): 33-46.

Humphries, C.J. and M.C. Ebach. - 2004. Biogeography on a Dynamic Earth. In: M.V. Lomolino and L.R. Heaney (eds.), Frontiers of biogeography: new directions in the geography of nature, pp. 67-86. Sinauer Associates, Inc. Publishers, Sunderland, Massachusetts.

Jackson, J.W. and G. Stiasny. - 1937. The Brachiopoda of the Siboga Expedition. Siboga-Expeditie, 27: 1-20.

Johnston, S.T. - 2004. The New Caledonia-D'Entrecasteaux orocline and its role in clockwise rotation of the Vanuatu-New Hebrides Arc and formation of the North Fiji Basin. In: A.J. Sussman and A.B. Weil (eds.), Orogenic Curvature: Integrating Paleomagnetic and Structural Analyses. Geol. Soc. Am. Spec. Pap., 383: 225-236.

Kroh, A., M.A. Bitner and S.P. Ávila. - 2008. Novocrania turbinata (Brachiopoda) from the Early Pliocene of the Azores (Portugal). Acta Geol. Polon., 58: 473-478.

Laurin, B. - 1992. Découverte d'un squelette de soutien du lophophore de type "crura" chez un brachiopode inarticulé: déscription de Neoancistrocrania norfolki gen. sp. nov. (Craniidae). C. R. Acad. Sci. Paris, Life Sci., 314: 343-350.

Laurin, B. - 1997. Brachiopodes récoltés dans les eaux de la Nouvelle Calédonie et des îles Loyauté, Matthew et Chesterfield. In: A. Crosnier (ed.), Résultats des Campagnes Musorstom. Volume 18. Mém. Mus. nat. Hist. natur., 176: 411-471.

Lee, D.E. - 1987. Cenozoic and Recent inarticulate brachiopods of New Zealand: Discinisca, Pelagodiscus and Neocrania. J. R. Soc. N. Z., 17: 49-72.

Lee, D.E. and C.H.C. Brunton. - 1986. Neocrania n. gen., and a revision of Cretaceous-Recent brachiopod genera in the family Craniidae. Bull. Br. Mus. nat. Hist. (Geol.), 40: 141-160.

Lee, D.E. and J.H. Robinson. - 2003. Kakanuiella (gen. nov.) and Thecidellina: Cenozoic and Recent thecideide brachiopods from New Zealand. J. R. Soc. N. Z., 33: 341-361.

Logan, A. - 1979. The Recent Brachiopoda of the Mediterranean Sea. Bull. Inst. Océanogr. Monaco, 72: 1-112.

Logan, A. - 2007. Geographic distribution of extant articulated brachiopods. In: P.A. Selden (ed.), Treatise on Invertebrate Paleontology. Part H. Brachiopoda Revised. Geological Society of America and University of Kansas, Boulder, Colorado and Lawrence, Kansas, 6: 3082-3115.

Logan, A. - 2008. Holocene thecideide brachiopods from the northwestern Pacific Ocean: systematics, life habits and ontogeny. Syst. Biodiversity, 6: 405-413.

Logan, A. and S.L. Long. - 2001. Shell morphology and geographical distribution of Neocrania (Brachiopoda, Recent) in the eastern North Atlantic and Mediterranean Sea. In: C.H.C. Brunton, L.R.M. Cocks and S.L. Long (eds.), Brachiopods past and present. Syst. Assoc. Spec. Vol., 63: 71-79.

Logan, A., C.N. Bianchi, C. Morri and H. Zibrowius. - 2004. The present-day Mediterranean brachiopod fauna: diversity, life habits, biogeography and paleobiogeography. In: J.D. Ros, T.T. Packard, J.M. Gili, J.L. Pretus and D. Blasco (eds.), Biological oceanography at the turn of the Millenium. Sci. Mar., 68(Suppl. 1): $163-170$.

Lüter, C., G. Wörheide and J. Reitner. - 2003. A new thecideid genus and species (Brachiopoda, recent) from submarine caves of Osprey Reef (Queenland, Plateau, Coral Sea, Australia). J. Nat. Hist. 37: 1423-1432.

MacFarlan, D.A.B., M.A. Bradshaw, H.J. Campbell, R.A. Cooper, D.E. Lee, D.I. MacKinnon, J.B. Waterhouse, A.J. Wright and J.H. Robinson. - 2009. Phylum Brachiopoda. In: D.P. Gordon (ed.), New Zealand Inventory of Biodiversity. Volume 1: Kingdom Animalia: Radiata, Lophotrochozoa, Deuterostomia, pp. 255-267. Canterbury University Press, Christchurch.

Motchurova-Dekova, N., M. Saito and K. Endo. - 2002. The Recent rhynchonellide brachiopod Parasphenarina cavernicola gen. et sp. nov. from the submarine caves of Okinawa, Japan. Paleontol. Res., 6: 299-319.

Pajaud, D. - 1970. Monographie des Thécidées (Brachiopodes). 
Mém. Soci. Géol. France (Nouv. Sér.), 112: 1-349.

Reeve, L. - 1862. A monograph of Crania. Conchologica Iconica, 13: 3 pp. without pagination. London.

Richardson, J.R. - 1973a. Studies on Australian Cainozoic brachiopods. 1. The loop development of Frenulina sanguinolenta (Gmelin 1790). Proc. R. Soc. Victoria, 86: 111-116.

Richardson, J.R. - 1973b. Studies on Australian Cainozoic brachiopods. 2. The family Laqueidae (Terebratellidae). Proc. R. Soc. Victoria, 86: 117-126.

Richardson, J.R. - 1979. Pedicle structure of articulate brachiopods. J. R. Soc. N. Z., 9, 414-436.

Richardson, J.R., I.R. Stewart and L. Xixing. - 1989. Brachiopods from China Seas. Chin. J. Ocean. Limnol., 7: 211-219.

Richer de Forges, B. - 1991. Les fonds meubles des lagons de Nouvelle-Calédonie: généralités et échantillonnages par dragages. In: B. Richer de Forges (ed.), Le benthos des fonds meubles des lagons de Nouvelle-Calédonie. Etudes and Thèses, ORSTOM, Paris, 1: 8-148.

Saito, M. - 1996. Early loop ontogeny of some Recent laqueid brachiopods. Trans. Proc. Palaeontol. Soc. Japan, 183: 485-499.

Saito, M., N. Motchurova-Dekova and K. Endo. - 2000. Recent brachiopod fauna from the submarine caves of Okinawa, Japan. The Fourth, Millennium, International Brachiopod Congress, $10^{\text {th }}-14^{\text {th }}$ July 2000. Abstracts.

Stenzel, H.B. - 1964. Stratigraphic and paleoecologic significance of a new Danian brachiopod species from Texas. Geol. Rundsch., 54: 619-631.

Thomson, J.A. - 1916. Additions to the knowledge of the Recent and Tertiary Brachiopoda of New Zealand and Australia. Trans.
Proc. N. Z. Inst., 48: 41-47.

Thomson, J.A. - 1918. Brachiopoda. In: Australasian Antarctic Expedition 1911-1914. Sci. Rep., ser. C, 4(3): 1-76.

Thomson, J.A. - 1927. Brachiopod morphology and genera (Recent and Tertiary). N. Z. Board Sci. Art, Manual 7: 1-338.

Zezina, O.N. - 1981a. Recent deep-sea Brachiopoda from the Western Pacific. Galathea Rep., 15: 7-20.

Zezina, O.N. - 1981b. The composition and the ways of formation of the thalassobathyal brachiopod fauna. In: A.P. Zuznetsov and N.A. Mironov (eds.), Benhos of the submarine mountains Marcus-Necket and adjacent Pacific regions, pp. 141-149. Academy of Sciences of the USSR, P.P. Shirshov Institute of Oceanology, Moscow [in Russian with English summary].

Zezina, O.N. - 1981c. New and rare cancellothyroid brachiopods. Tr. Inst. Okeanol., 115: 155-164. [in Russian with English summary]

Zezina, O.N. - 1985. Sovremennye brakhiopody i problemy batialnoj zony okeana. Nauka, Moskva.

Zezina, O.N. - 1987. Brachiopods collected by BENTHEDI-Cruise in the Mozambique Channel. Bull. Mus. nat. Hist. natur., 4A(9): 551-563.

Zezina, O.N. - 1994. Recent brachiopods from underwater rises of the Western part of the Indian Ocean. Tr. Inst. Okeanol., 129: 44-52 [in Russian with English summary].

Scient. ed.: M.P. Olivar.

Received October 22, 2009. Accepted January 21. 2010.

Published online June 29, 2010. 